\title{
Az Országos Sebészeti Intézet emléke a Semmelweis Egyetem I. sz. Sebészeti Klinikáján
}

\author{
WELTNER JÁNOS, SZIJÁRTÓ ATTILA
}

Semmelweis Egyetem, I. sz. Sebészeti Klinika, Budapest

A minőségügy, a tevékenységünk hibáinak, sikereinek, kudarcainak elemzése régóta része a sebészetnek. Hosszú időszakon keresztül ki-ki a maga, illetve klinikájának/osztályának eredményeit elemezte. E tevékenység, valamint ezek eredményeként született közlések, közlemények vitatása során alakultak ki azok a mutatók, melyek a sebészeti ténykedés minősítésére alkalmasak.

A hatvanas évek végére jutott odáig a hazai egészségügyi kormányzat, hogy e tevékenységnek szervezeti keretet adjon. A fóvárosi egyetemi klinikákra épülve megalapították a szakmai Országos Intézeteket. Amelyik szakmának akkoriban nem volt klinikai megjelenése, azok önálló betegellátó intézetként álltak fel, mint például az onkológia, reumatológia, idegsebészet, baleseti sebészet, tüdőgyógyászat, laboratóriumi orvostan, sportegészségügy terén.

Az Országos Sebészeti Intézet (OSI) a BOTE I. sz. Sebészeti Klinikájára települt 1-1 igazgatóval, igazgatóhelyettessel és módszertani osztályvezetővel, akik a mindennapi klinikai munka mellett és 2 adminisztrátor által segítve végezték e feladatukat. Az OSI 1972-ben végzett először országos adatgyüjtést (dr. Rubányi Pál, dr. Szécsény Andor, dr. Barna László, dr. Alánt Oszkár), mely során minden hazai sebészet jelentette az 1971. évi teljes beteganyagának kórisméjét, mütétjét, a betegség és a kezelés szövődményeit, a halálozást, a kezelőorvos rangját stb. Az adatokat az egyetem számítóközpontjának R5 számítógépén az OSI rendszerterve alapján ( $d r$. Weltner János) dolgozták fel. Az országos, a megyei átlagokat és az összehasonlítható intézetek (klinikák, megyei kórházak, városi kórházak) átlagait képeztük és ismertettük meg a sebésztársadalommal, mintegy tükröt tartva önmagunk elé: így dolgozunk mi. Ebből ki-ki levonhatta a következtetést: mely tevékenységére lehet büszke, és hol van javítanivalója.

Ez az úttörő munka is hozzájárult az ESZTIK keretében, a Tolna Megyei Kórház (TOMEGYI - kórlapfej) szervezésében az országos adatgyüjtési rendszer kiépüléséhez (a fentiek mellett $d r$. Horányi János), a kórházi statisztikai adatlap kialakulásához. Az elv az volt, hogy lehet korrekt szakmai adatgyüjtést végezni, ennek adataival tilos viszszaélni, de kötelező az adatokkal élni. Az OSI a jelentéseit bemutatta a Kollégiumának, melynek tagjai a klinikavezető professzorok mellett rotációs alapon a megyei szakfóorvosok voltak. Az OSI a kollégium határozata alapján jelentett a minisztériumnak, melynek szakmapolitikai főosztályára a klinika rendszeresen delegált 1-1 fiatal sebészt, remélve, hogy kedvet kap a szakmapolitikai munkához. (Legutóbb $d r$. Winternitz Tamást, elötte $d r$. Forgács Andrást.)

E munkából szükségszerüen következett az asztali számítógépek megjelenésekor, hogy az egyetemi számítóközponttal együttmüködve az OSI anyagi eszközeit használva kidolgoztuk a releváns betegadatok rögzítését egy MOD-81 típusú $\mathrm{CP} / \mathrm{M}$ operációs rendszerü, 8 bites $\mathrm{Z} 80$ processzorral vezérelt, $4 \mathrm{db} 8$ inches floppymeghajtóval - merevlemez nélkül - szerelt számítógépre. E rendszer a folyamatos fejlesztés eredményeként IBM-PC környezetre átírt változata labor, mütéti, gyógyszerosztó, járóbeteg ellátó, felvételi előjegyző és statisztikai moduljaival széles körü népszerüségnek örvendett, több mint 50 hazai kórház vette meg és használta saját adminisztratív feladatellátásán túl a szakmai és finanszírozási adatjelentésekhez is. Természetesen az OSI is az így összeállított teljes körünek mondható országos adatbázist használta a továbbiakban a saját elemző munkáihoz. A munka keretében vett részt az OSI a nosocomialis fertőzésekkel kapcsolatos módszertani levél elkészítésében, majd tekintélyünk okán a minisztérium kódkarbantartó munkacsoportjainak tevékenységében ( $d r$. Weltner János), a Magyar Orvosi Kamara megalakításában (dr. Sitkéry Iván, dr. Forgács András, dr. Horányi János), annak jogi, díjtételegyeztető és érdekvédelmi bizottságában, illetve elnököt is adott a MOK-nak $d r$. Kupcsulik Péter személyében.

A rendszerváltás utáni első évtizedet követően az országos szakmai minőségügyi tevékenység nem kapott olyan nagy hangsúlyt. Ez annál is inkább sajnálatos, mivel más európai országokban e terület fejlődőben van. Az OSI tevékenysége megszünt. Azóta a Szakmai Kollégiumok infrastruktúra nélkül próbálnak megfelelni feladataiknak.

A cikk a Creative Commons Attribution 4.0 International License (https://creativecommons.org/licenses/by/4.0/) feltételei szerint publikált Open Access közlemény, melynek szellemében a cikk bármilyen médiumban szabadon felhasználható, megosztható és újraközölhetö, feltéve, hogy az eredeti szerző és a közlés helye, illetve a CC License linkje és az esetlegesen végrehajtott módosítások feltüntetésre kerülnek. (SID_1) 